
A C T A
I C $\mathrm{H} \mathrm{T} \mathrm{H} \mathrm{Y}$

Andrzej ORLOWSKI

\title{
HYDROACOUSTIC SURVEYS OF FISH DISTRIBUTION IN RELATION TO ENVIRONMENT
}

\author{
Sea Fisheries Institute, Gdynia, Poland
}

Acoustic data collected during routine surveys can be used to improve our knowledge of marine ecosystems. Some neyt ideas of presentation and processing of acoustic, environmental and biological measurements are presented.

In the method proposed, called macrosounding, the vertical distribution of fish biomass is generated by computer according to a scale selected on the basis of spatial and temporal correlation of the phenomena observed. The picture can be enriched by other factors, such as isotherms or isohalines, with the use of a multidimensional matrix of environmental, biological and acoustic data from the surveyed area.

Practical application of the presented method is exemplified by results of surveys on distribution of fish in relation to environmental conditions in the Polish fishery zone. Distributions for the spring 1983 and 1985 and for the summer 1983, 1987, 1988 are presented and discussed.

\section{INTRODUCTION}

During the period of 1981-1987, six multi-disciplinary research cruises of RV „Profesor Siedlecki” were carried out within the Polish fishery zone of the Baltic Sea, using a dense grid of sampling stations. The main objective was to get a wider overview of environmental conditions and determine the distribution and stocks of commercial fish resources. Hydroacoustic estimation of fish biomass was conducted with the use of EK 38 echo-sounder and QM MkII echointegrator. A detailed characteristics of the method used and the basic results are described by Elwertowski et al. (1984), Orłowski (1982, 1984, 1985, 1988, 1989 and in print (a)). 


\section{MATERIALS AND METHODS}

Based on acoustic and environmental data collected during the cruises mentioned, and using a new approach to the materials collected (Orłowski 1989), characteristics of fish distribution patterns in relation to environmental conditions were determined and analysed. The first step for a geographical analysis of the factors measured was to divide the whole surveyed area into 600 elementary squares to form the matrix $\left\{a_{i j}\right\}$ of 30 columns and 20 lines (Fig. 1.A.). The side of each square amounted to
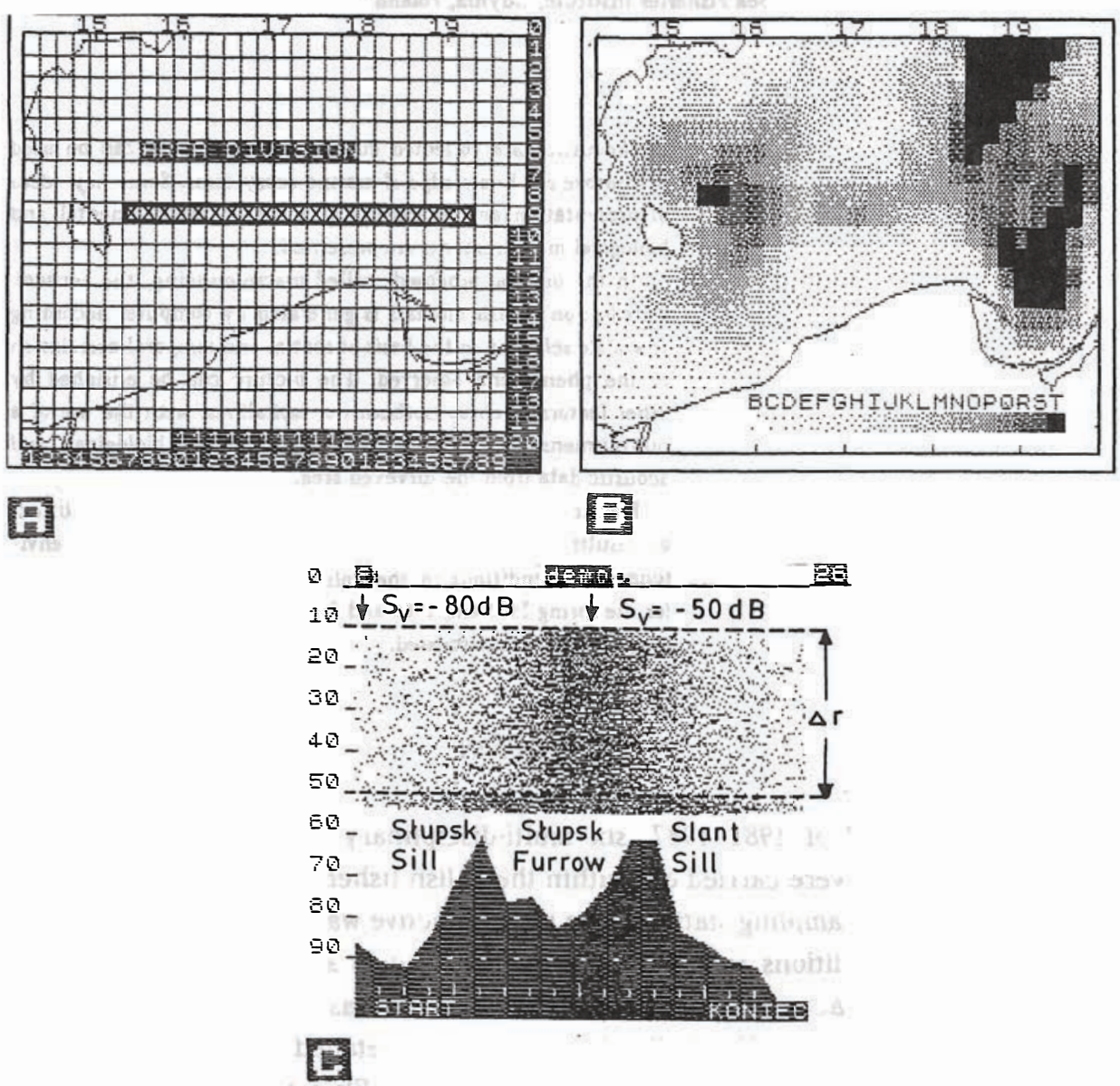

Fig. 1. General characteristics of the methods used:

$A-$ division of surveyed area as $\left\{a_{i j k}\right\}$ matrix of elementary squares; complex transect localization,

$B$ - depth distribution of surveyed area, expressed as $\left\{a_{i j k}\right\}$ matrix elements $(B=5-10 \mathrm{~m}, \mathrm{C}=10-15 \mathrm{~m}, \ldots, \mathrm{T}>95 \mathrm{~m})$

$\mathrm{C}$ - example of artificially-generated fish distribution along the complex transect (fish density expressed by $S_{V}$ changes from $-80 \mathrm{~dB}$ at the borders up to $-50 \mathrm{~dB}$ in the middle of the transect) 
approximately 7 nautical milles, which was enclosed between the mean distance between oceanographic stations $(10 \mathrm{Nm})$ and the typical radius of autocorrelation of biomass density samples $(5 \mathrm{Nm})$, observed in the surveyed area. For each elementary square, the mean value of bottom depth was evaluated from "The Southern Baltic Sea" map edited by the Hydrographic Bureau of the Polish Navy. The bathymetric map of the area of surveys, transferred to computer memory, is shown in Figure 1.B.

A dense grid of acoustic transects $\left(1 \mathrm{Nm}\right.$ for $\left.8 \mathrm{Nm}^{2}\right)$ and oceanographic sampling stations (1 station per approx. $100 \mathrm{Nm}^{2}$ made it possible to evaluate magnitudes of acoustic and enviromnental parameters for each elementary square $a_{i j}$ of the matrix $\left\{a_{i j k}\right\}$. Using the geographical analysis and extrapolating data recorded, the matrix $\left\{a_{i j k}\right\}$ was completed and prepared for subsequent operations.

The matrix $\left\{\mathrm{a}_{\mathrm{ijk}}\right\}$ used for description of distribution patterns of fish in relation to environmental factors contained values of the following parameters:

- column scattering strength $S_{\text {vc' }}$,

- lower and upper limits of fish echoes layers,

- mean depth of fish echoes layers ( depth of median of depth biomass distribution),

- time of day,

- depths of 2 unit intervals of isotherms (as $+2^{\circ},+4^{\circ},+6^{\circ}, \ldots,+18^{\circ},+20^{\circ} \mathrm{C}$ ) and isoha. lines (as $2 \%, 4 \%, 6 \% 0, \ldots, 18 \%$, 20\%0).

Correlation of the pattern of fish distribution and environmental conditions along the transect required a new approach to visualisation of acoustic data on fish biomass distribution.

Traditionally, the results of sounding are presented in the form of echograms. However, no-one nobody is able to analyse ecosystem features when the information on fish distribution is dispersed over so many meters of recordings. The author proposes a new method of graphical presentation of vertical fish biomass distribution along the transect. The method has been called macrosounding. The macrosounding is based on computer generation of vertical fish distribution according to a scale chosen in relation to a spatial and temporal correlation of the observed phenomena.

Fig. 1.C. presents, as an example, an artificially generated layer of fish, dispersed between $10 \mathrm{~m}$ and $55 \mathrm{~m}$, the mean depth of fish ocurrence being $50 \mathrm{~m}$. In the upper layer, fish density, expressed by volume scattering strength $S_{v}$, is enclosed between $-80 \mathrm{~dB}$ and $-50 \mathrm{~dB}$. The algorithm keeps the mean distance between neighbouring dots as a randomly modulated variable with the mean value related to the biomass density of a cross-section, expressed by $S_{v}$. The manner of filling the vertical lines with dots is matched to the interval of extreme values of $S_{v}$, recorded for all Baltic cruises $(-80 \div-50 \mathrm{~dB})$. A horizonal axis of the diagram corresponds to the distance units of a transect (sides of $a_{i j}$ squares), chosen from the matrix $\left\{a_{i j k}\right\}$. The units of 
the transect are marked in the lower part of the diagram and the depths in meters along the right vertical axis.

A synthesis of macrosounding and a graphical expression of isotherms and isohalines, applied for wider comparisons in this paper, was called the method of complex transect. Geographical localization of the standard complex transect of Polish fishery zone, used in all comparisons presented below is shown in Fig. 1.A. The localization was predicted by analysis of Baltic waters dynamics. As a result, the transect was chosen along the route of ocean water inflows (Fig. 1.B.) through Bornholmsgattet, passing through the Bornholm Deep, Słupsk Bank, Słupsk Furrow, Slant Sill and Gdańsk Deep (Fig. 1.C.).

All analyses were conducted for a daytime fish distribution. If data on daytime configuration of fish distribution were not available for the given $a_{i j}$ square, the upper line of the diagram was not filled. When a break was less than 2 units ( $a_{i j}$ squares), the extrapolation of neighbouring squares data was performed.

The complementary description of methods used to characterize the fish distribution in relation to environmental conditions was given by Orłowski (1989).

\section{RESULTS AND DISCUSSION}

Patterns of fish distribution, expressed in the form of complex transects of the Polish fishery zone, have to be presented and analysed by the season of the year, which has an important impact on all the observed factors. Seasonal characteristics of fish distribution in the Baltic Sea in relation to environmental conditions was described by Orłowski (in print b).

The data available, collected during the cruises of RN „Profesor Siedlecki”, allowed to compare the fish distribution patterns for two different seasons: the spring in 1983 and 1985 (Fig. 2) and the summer in 1983, 1987, 1988 (Fig. 3 and Fig. 4). In the first case, the situation was mostly dependent on a spawning concentration of sprat, while in the second one the fish were dispersed over the whole area in feeding concentrations.

With respect to the spring, it is important to underline that both patterns, characterising 1983 and 1985, were determined for widely differing oceanographic situations, especially in the area of sprat spawning grounds. In the year 1983, a significant inflow of North Sea waters, clearly seen by isohalines shapes, took place (Wojewódzki and Piechura 1983; Wojewódzki 1987), while in 1985 stagnation of water masses was observed (Fig. 2.C.).

In the year 1983, a sprat spawning concentration was localized off the west slope of the Słupsk Sill, in waters with temperatures of $4-6^{\circ} \mathrm{C}$ and salinities of $10-16 \%$ (Fig. 2.C.), at depths of 50-70 m. Two years later in the same area and at the same depths, cold winter waters below $+3^{\circ} \mathrm{C}$ appeared. The spawning concentration had a 

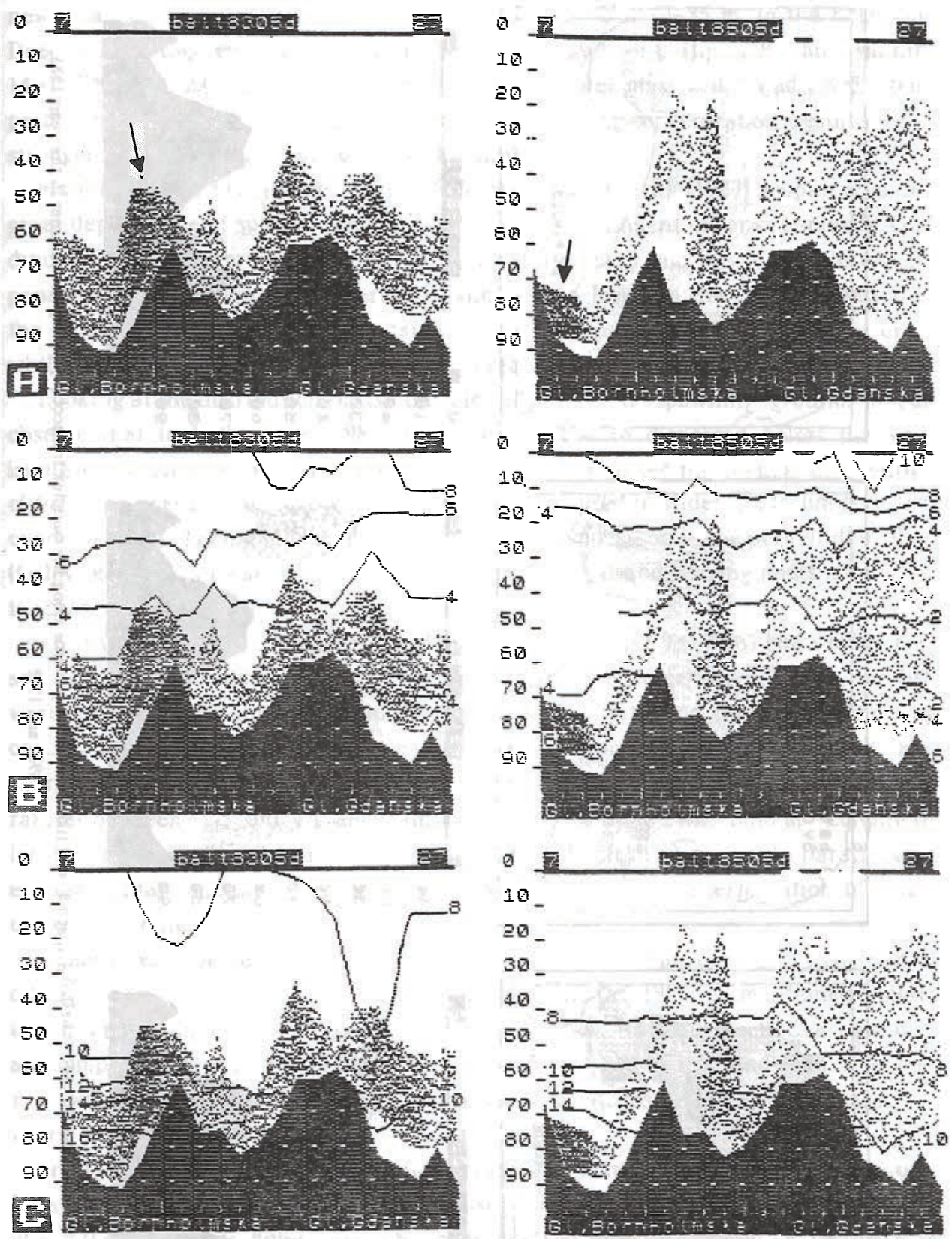

Fig. 2. Comparison of fish distribution pattern and environmental conditions during the spring of 1983 and 1985 along the complex transect: A - fish distribution patterns, B - fish distribution and isotherms, C - fish distribution and isohalines 

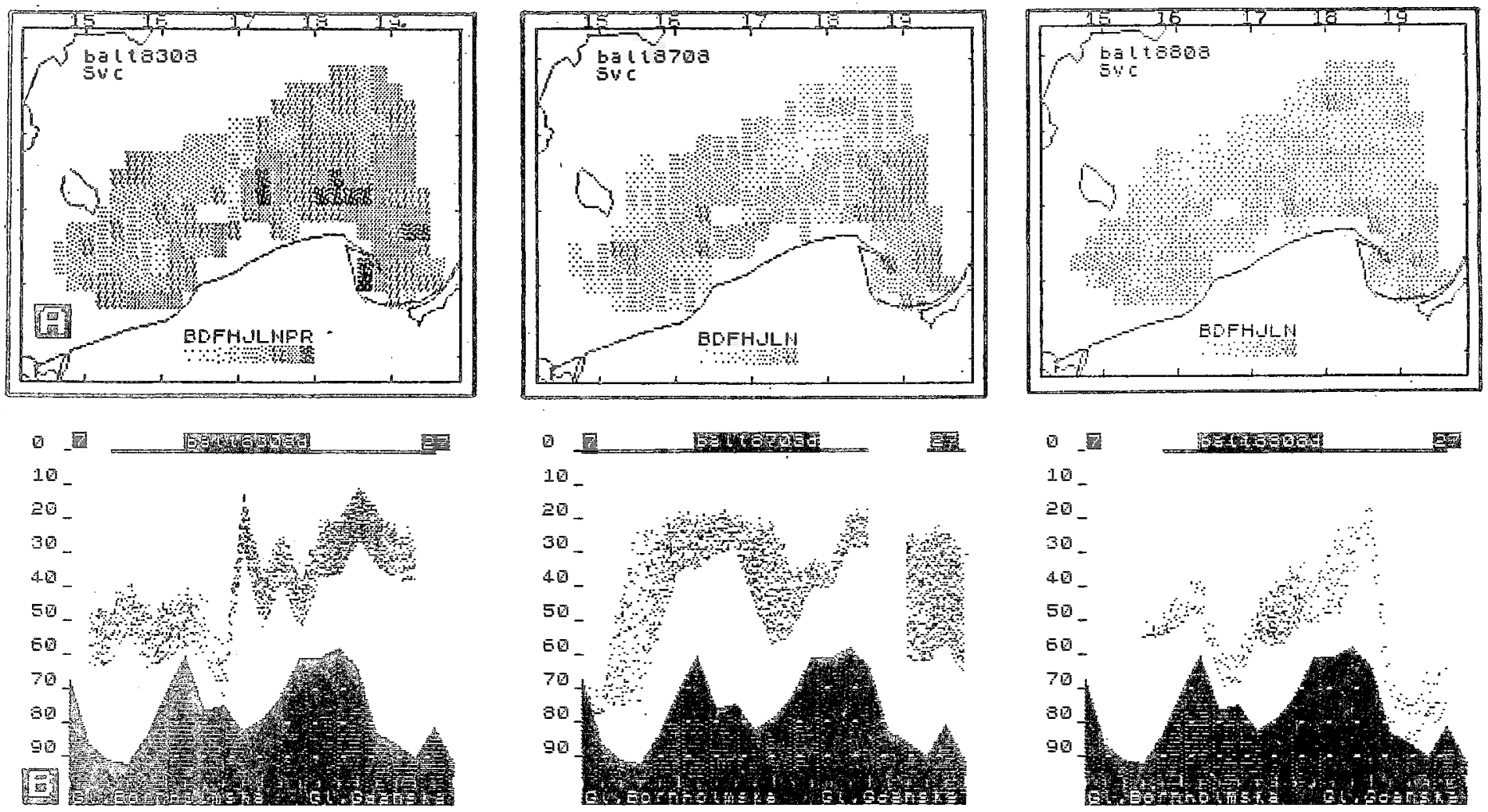

Fig. 3. Comparison of column scattering strength $\mathrm{S}_{\mathrm{vc}}$ map $(\mathrm{A})$ and fish distribution patterns along the complex transect (B) during the summer in the years 1983 , 1987 and 1988 
new localization, more to the west (Fig. 2.A.) at depths of $70-85 \mathrm{~m}$, in the Bornholm Deep, where the temperature was between $+4^{\circ} \mathrm{C}$ and $+6^{\circ} \mathrm{C}$ (fig. 2.B.) and salinity 14-15.7\% (Fig. 2.C.). A decrease in the volume of water mass which had similar temperatures as those determined in 1983 for the spawning concentration, resulted in a stronger concentration of fish for spawning in 1985.

Mańkowski (in Lomniewski et al. 1975) and Elwertowski (1987) emphasized the great dependence of spawning results and future recruitment on environmental conditions during the sprat spawning. The sprat pelagic eggs and larvae are closely dependent on water density, temperature, and oxygen level. In the case shown above, the temperature factor $\left(4-6^{\circ} \mathrm{C}\right.$ limits) seemed to belong to the most important ones, while the values of salinity in the spawning area were enclosed within wider limits.

Looking at the distribution of fish outside the area of the spawning ground, we can observe that in both cases $(1983,1985)$, the fish were dispersed below the $+4^{\circ} \mathrm{C}$ isotherms. A different vertical temperature structure affected the vertical distribution of fish. The presence of cold winter waters 1985 resulted in wider depth limits of fish concentrations. Taking into consideration species composition of the periods described (Orlowski 1989), we can relate the 1983 picture to sprat and herring and that of 1985 to sprat stocks.

For the summer, a comparison of three cruises from 1983, 1987 and 1988 is presented in Figure 3 and Figure 4. During the day in the summer feeding time, the fish were dispersed within the whole survey area. The sprat and the juvenile herring occupied upper heterothermal layers, with temperatures between $8^{\circ}$ and $18^{\circ} \mathrm{C}$ and salinities lower than $8 \%$. The herring appeared mainly in deeper waters, with temperatures between $+2.5^{\circ}$ and $6^{\circ} \mathrm{C}$ and salinities from $7.8 \%$ up to $14 \%$. Similar conditions for herring were described by Fetter $(1976,1986)$. Such differences of characteristic enviromnental conditions for each species are important for interpretation of distributions presentes in Figs. 3 and 5.

Summer environmental conditions along the complex transect were significantly different between the years 1983, 1987 and 1988. In the 1983, as mentioned before, the water was under the influence of a stronger inflow from the North Sea, salinities and temperatures of deeper layers being higher than those in 1987 and 1988 . The year 1987 was the coldest and winter waters, with temperatures below $+2^{\circ} \mathrm{C}$, appeared between $60 \mathrm{~m}$ and $70 \mathrm{~m}$.

In Fig. 3.A., geographical distributions of column scattering strength $S_{v c}$ are shown for all the years compared. It is easy to observe a systematic, year-by-year, decrease of $S_{v c}$, the magnitude being proportional to surface biomass density. A decrease in biomass density was observed in the coastal area at first (1983-1987), expanding to deeper zones (1987-1988). In 1983, the maximum value of $S_{v c}$ amounted to $-34.9 \mathrm{~dB}$ (minimum $=-64.2 \mathrm{~dB}$ ), in $1987:-43.0 \mathrm{~dB}$ (minimum $=-71.1 \mathrm{~dB})$, and in 1988 : $-45.6 \mathrm{~dB}$ (minimum $=-71.4 \mathrm{~dB}$ ). If we assume that a standard deviation for 1983 was 

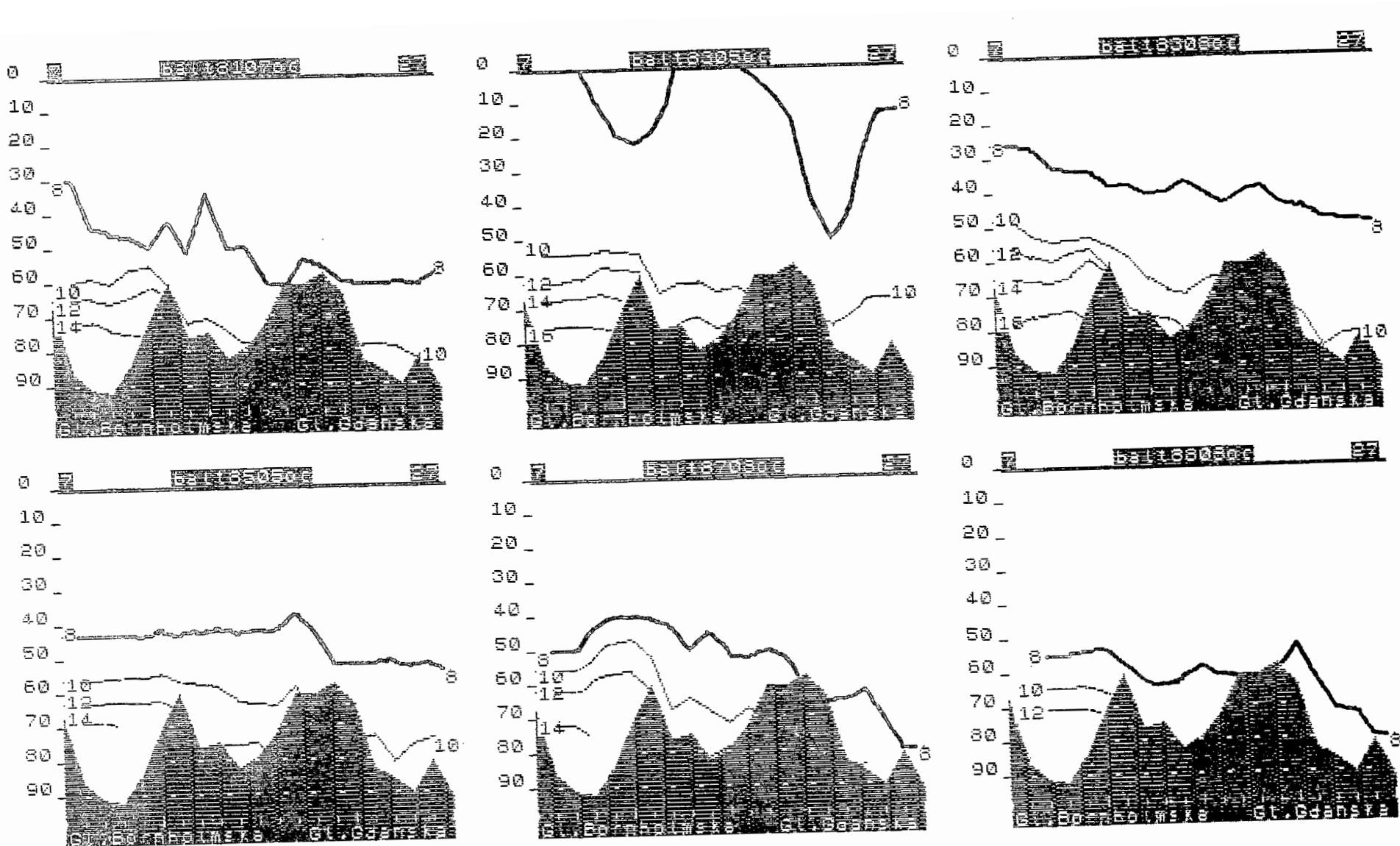

Fig. 4. General patterns of isohalines along the complex transect over the years 1981-1988 
8

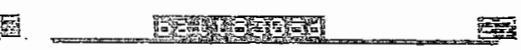

10

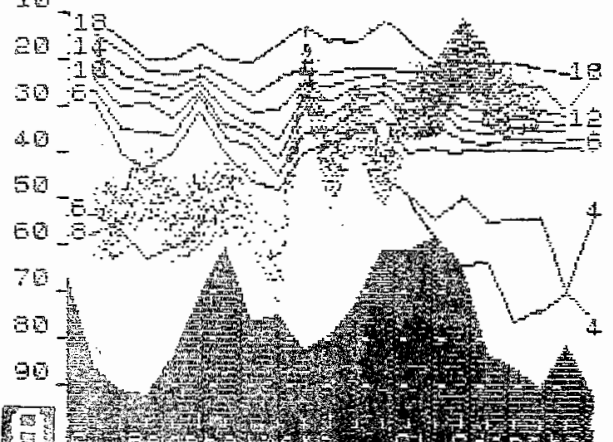

F

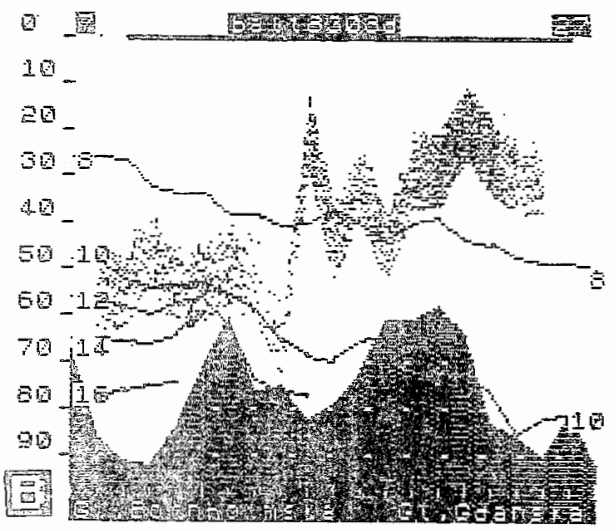

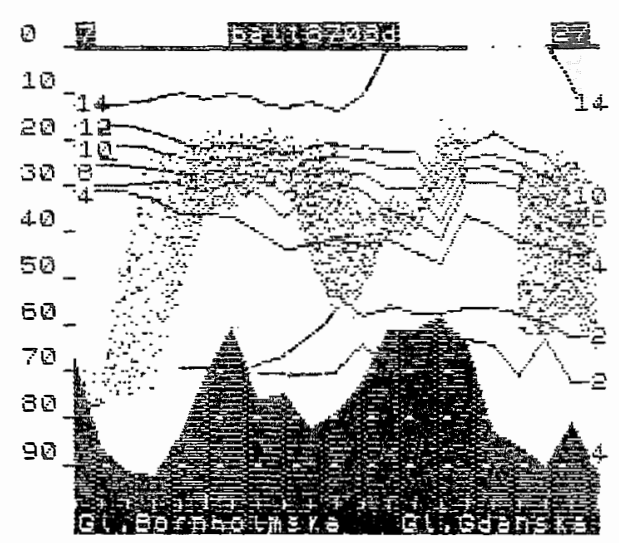

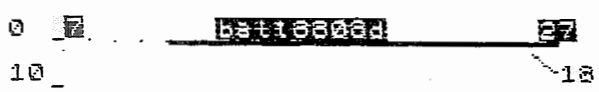

20 - $1 E$

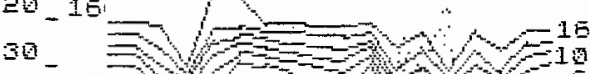

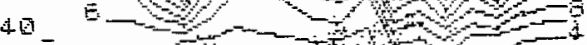

$501-4-\therefore$ 60
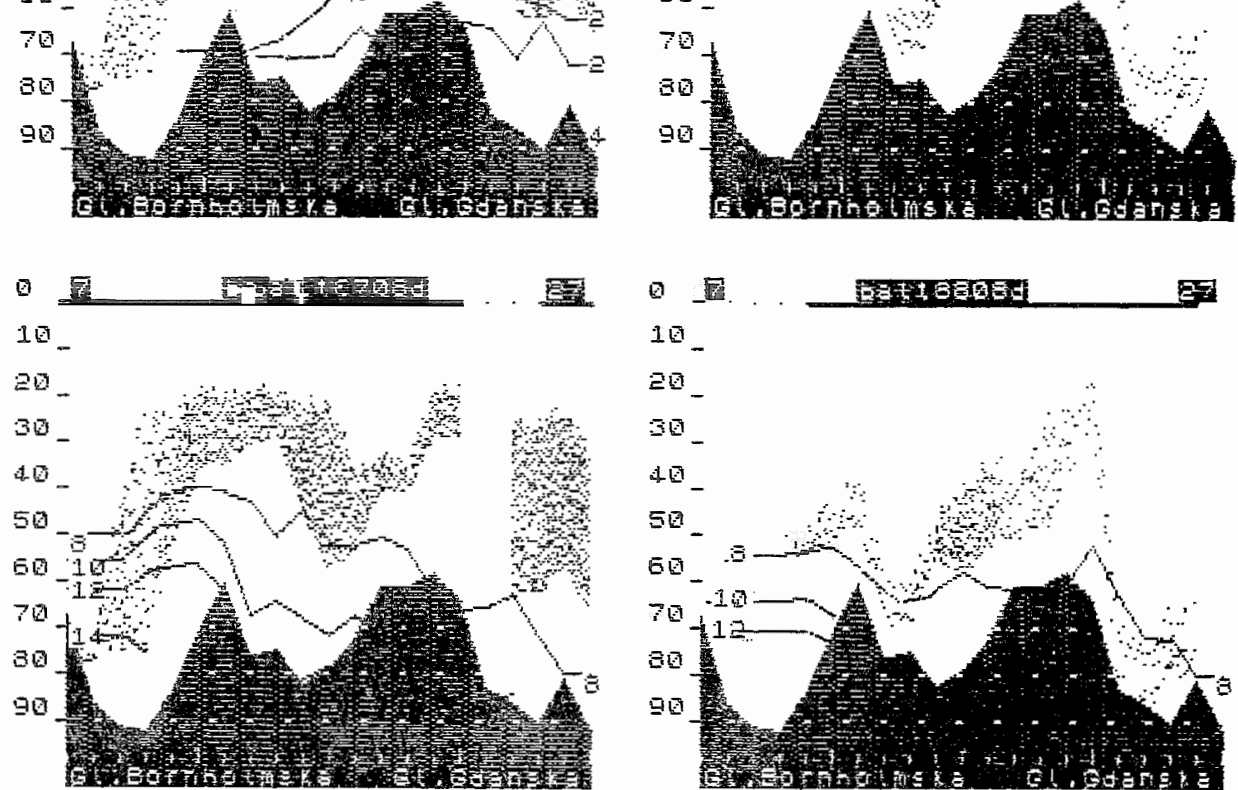

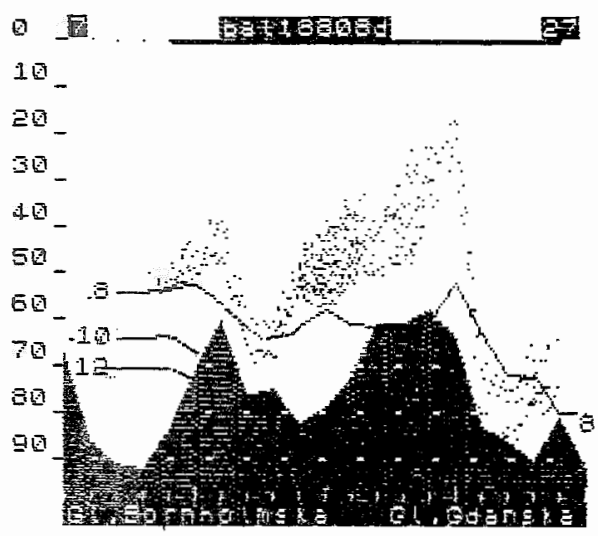

Fig. 5. Comparison of fish distribution patterns and isotherms (A) and isohalines (B) along the complex transect during the summertime in the years 1983 1987 and 1988 
$5.23 \mathrm{~dB}$, in $1987: 5.06 \mathrm{~dB}$, and in 1988: $4.39 \mathrm{~dB}$, we can conclude that the reduction of biomass appeared at first in the areas of the highest fish biomass densities - and horizontal fish distribution has become more uniform at last. The observed reduction of biomass can be correlated to an increasing stagnation of the Baltic waters. In Fig. 4, isohalines along the complex transect over the years 1981-1988 are shown to demostrate a strong dependence of waters (mostly salinity) on the inflows from the North Sea. The position of the $8 \%$ isohaline, considered as the hypothetic border between the main Baltic water masses, shows longterm trends over the past 8 years. The situation shown indicates a long stagnation period of the Baltic waters since 1985.

The total biomass for 1983 and 1987 divided between sprat and herring stocks (a near-equal percentage), while in 1988 herring percentage was the highest $(72 \%)$.

Comparing the vertical distribution of fish (Fig. 3.B.), some common features can be observed lin the patterns. One of them is the correlation of fish depth limits and the bottom profile. Generally, mean fish depth is proportional to the bottom depth - especially for herring recordings. Distributions in the western part of the transect (Bornholm Deep) and in the Stupsk Furrow corresponded to herring. In 1987, herring concentrations were observed in the Gdańsk Deep as well. In 1988, herring was practically the only species observed along the transects (except for the area near the Slant Sill). If we consider the shape of isotherms and isohalines (Fig. 5), we can conclude that the main factor influencing the vertical fish distribution was related to temperatures, while the salinity was not simply correlated to the fish distribution pattern. The fish distribution, according to the species given, was correlated to the depth limits of their characteristic isotherms. For example, in 1983, the presence of warmer inflow waters (over $+8^{\circ} \mathrm{C}$ ) below $60 \mathrm{~m}$ depth caused a displacement of herring int lower depths $(<60 \mathrm{~m})$, with temperatures below $+6^{\circ} \mathrm{C}$. Similar reaction was connected with the appearance of cold winter (below $+2^{\circ} \mathrm{C}$ ) in 1987 . The salinity interval for waters occupied by herring was very wide $(7.8 \%-14 \%)$ and a correlation of the herring vertical distribution and the shapes of isohalines was not observed.

The sprat was generally present in upper layers of waters with a lower salinity, being mostly localized in the eastern part of the transect.

\section{CONCLUSSION}

Application of the complex acoustic transect to correlate the fish distribution pattern in relation to environmental factors made it possible to determine the types of existing relationships and to estimate them, according to the requirements chosen. As a consequence, the model of the marine ecosystem can be significantly broadened to give wider possibilities of estimating the influence of environmental factors on the basic biological processes and, finally, on the state of the fish resources. The analysis of the fish distribution patterns in relation to enironmental conditions showed the impor- 
tance of two basic factors. The first of them was related to a seasonal modulation of water temperatures and the dependence of the fish distribution pattern according to the season, year, and species. It is important to underline the differences between sprat and herring environmental requirements during the feeding and spawning seasons, as shown in this paper.

The second factor was dependent on inflows from the North Sea, having an important impact on deeper water masses. The appearance of the inflows is the result of coincidence of many, mostly metereological, factors and it is not a simple periodical phenomenon (Matthäus 1982).

The significance of both factors, deeply influencing the shape of the pattern of fish distribution, was shown by applying the complex transect analysis based on acoustic, biological and environmental data. Mathematical expressions of correlation between the fish distribution and the environmental factors can be estimated by statistical analysis of the matrix $\left\{\mathrm{a}_{\mathrm{ijk}}\right\}$, containing the values of all necessary parameters, with the use of the methods presented in Orłowski (1989).

\section{REFERENCES}

Elwertowski J., A. Onluwslki, S. Richert, 1984: Badania oceanograficzno-rybackie południowego Bał̇tyku prowadzone w maju 1983 r. na r.v. „Profesor Siedlecki” Biul. MIR, 1-2: 3-15.

Elwertowski J., 1987: Zasoby i połowy szprota bałtyckiego w latach 1975-79. Stud. Mater. MIR, ser. B, 55: $81-113$.

Fetter M.E., 1976: O sviazi niekatoryh gidrologicheskih faktorov s raspriedieliniem nagulnyh skoplenij sieldi v iuznoi Baltikie. Fish. Forsch., 14,1:17-19.

Fetter M.E. A.P. Davidiulk, 1986: Sezonnoje raspriedielienije sieldiej iuznoi Baltiki i faktorov sredy. Fish. Forsch., 24,2: 16-19.

ILomniewski K., W. Manikowski, J. Zaleski, 1975: Morze Bałtyckie. PWN. Warszawa.

Matthäus Woy 1982: Recent trends variations of oceanological parameters in the Baltic Sea. Proc. 13th Conf. Baltic Oceanographers; Helsinki, 2: 535-547.

Orlowski A., 1982: Zasoby ryb polskiej strefy Bałtyku oszacowane metodą hydroakustyczną podczas rejsu r.v. „Profesor Siedlecki” w 1981 r. Biul. MIR 1-6/69-74: 23-28.

Orlowski A. 1984: Multichannel echo-integration and its application for determinig of relationships between fish distribution and environmental conditions. Biul. MIR, 1-2/93-94: 19-24.

Onlowski A., 1985: Rozmieszczenie i wielkošć zasobów ryb w polskiej strefie rybolówstwa morskiego określone metodą hydroakustyczną rejs r.v. „Profesor Siedlecki” 23.V-5.VI.1985 r. Biul. MIR, 5-6/91-92: 10-19.

Orlỉowski A., 1988: Rozmieszczenie i wielkošć zasobów ryb poludniowego Baîtyku okres̊lone metodą hydroakustyczną podczas rejsu r.v. „Profesor Siedlecki” w sierpniu 1987 r. Biul. MIR, 1-2/105-106: 52-61.

Orlowsski A., 1989: Zastosowanie akustycznych metod do badań rozmieszczenia ryb i warstw rozpraszających na t̂le środowiska morskiego. Stud. Mater. MIR, B, 57, 134 pp.

Orlowslki A.o (in press) (a): Rozmieszczenie i wielkošć zasobów ryb w polskiej strefie rybolówstwa morskiego określone metodą hydroakustyczną (rejs r.v. „Profesor Siedlecki” 1988.08.15-09.09). Biul. MIR.

Orlowski. $\mathbb{A}_{\text {og }}$ (in press (b)): Seasonal fluctuations of biomass distribution based on results of hydroacoustic surveys of Polish fishery zone. J. Fish. Res.

Wojewódzki To, 1987: Dynamika wód, temperatura, zasolenie i zawartošć tlenu w Bał̣tyku. Rap. MIR, 1984-1985: 13-17. 
Wojewódzki T., J. Piechura, 1983: In-flows of North Sea waters in the Baltic Sea during November 1982-May 1983. ICES C.M. 1983/C:6.

Author's address:

Sea Fisheries Institute

ul. Kołłątaja 1

81-345 Gdynia

Polska (Poland) 